\title{
Heliaquanoids A-E, Five Sesquiterpenoid Dimers from Inula helianthus-aquatica
}

Zai-Qin Zheng, ${ }^{\dagger}$ Wen-Jun Wei, ${ }^{\dagger}$ Junmin Zhang, ${ }^{\dagger, *}$ Hang-Ying Li, ${ }^{\dagger}$ Kai Xu,${ }^{\S}$ Jiayuan $\mathrm{Xu}$, "Bencan Tang, "Ya Li, ${ }^{*, \dagger}$ and Kun Gao*,†

†State Key Laboratory of Applied Organic Chemistry, College of Chemistry and Chemical Engineering, Lanzhou University, Lanzhou 730000, People's Republic of China

School of Pharmacy, Lanzhou University, Lanzhou 730000, People's Republic of China

${ }^{\S}$ College of Pharmaceutical Science, Zhejiang University of Technology, Hangzhou 310014, P. R. China

"Department of Chemical and Environmental Engineering, the University of Nottingham Ningbo China, Zhejiang 315100, China 


\section{ABSTRACT:}

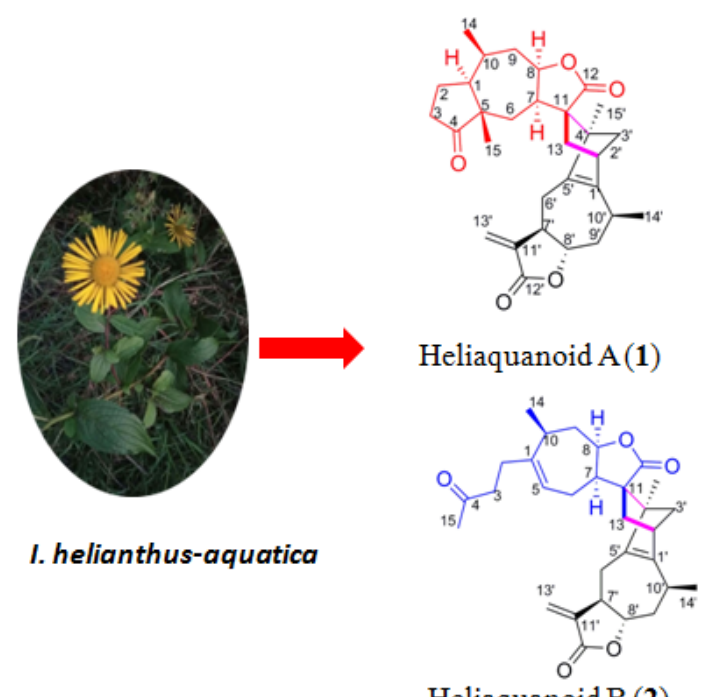

Heliaquanoid B (2)

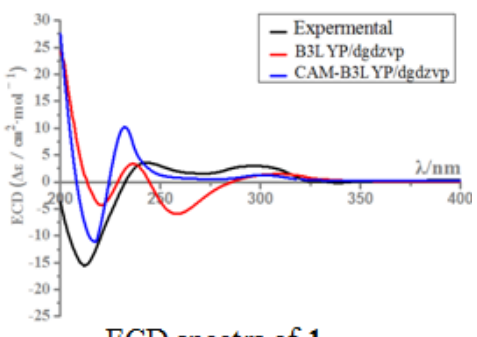

ECD spectra of 1

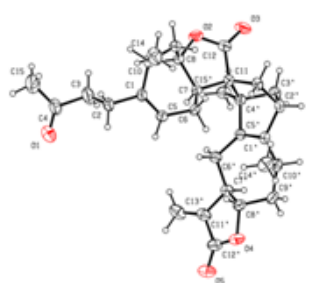

Crystal structure of 2

Heliaquanoid A (1), the first exo-2,4-linked Diels-Alder adduct between a pseudoguaianolide dienophile and a guaianolide diene, and heliaquanoids B-E (2-5), four new 2,4-linked Diels-Alder adducts between a xanthanolide dienophile and a guaianolide diene, were isolated from stems and leaves of Inula helianthus-aquatica. Their structures were determined by the NMR spectroscopy, modified Mosher's method, electronic circular dichroism, and X-ray diffraction analysis. Compounds 2 and 3 exhibited moderate cytotoxic activities against HL-60 cells with $\mathrm{IC}_{50}$ values of 7.5 and $4.9 \mu \mathrm{M}$, respectively. 
Sesquiterpenoid dimers (SDs) have attracted the attention of organic chemists and pharmacologists due to their diverse structures and bioactivities in recent years. ${ }^{1}$ SDs have been reported to be a characteristic class of component in the genus Inula in previous investigations. ${ }^{2}$ In our research for structurally interesting and bioactive SDs, five new SDs (Figure 1) were isolated from Inula helianthus-aquatica. Heliaquanoid A (1) was the first 2,4-linked carbon skeleton containing a pseudoguaianolide and a guaianolide units. Heliaquanoids B-E (2-5) were four new 2,4-linked SDs between a xanthanolide dienophile and a guaianolide diene. To the best of our knowledge, only three 2,4-linked SDs composed of xanthanolide and guaianolide units were reported and their absolute configurations have not been determined. ${ }^{3}$ Herein, we report the isolation, structural elucidation, and the cytotoxicity of these compounds.
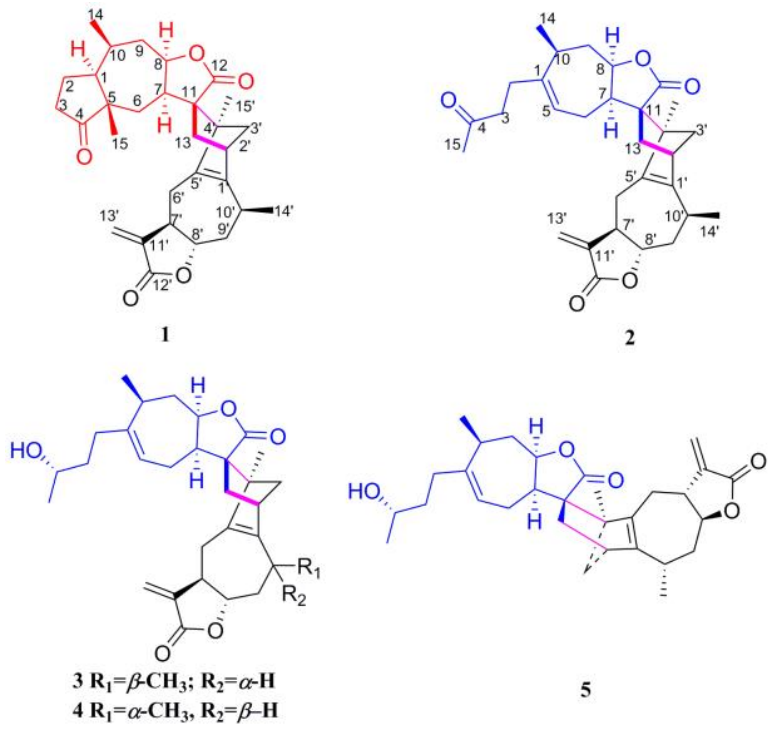

Figure 1. Chemical structures of heliaquanoids A-E (1-5).

Heliaquanoid A (1) was obtained as a colorless oil. Its molecular formula $\mathrm{C}_{30} \mathrm{H}_{38} \mathrm{O}_{5}$ was established by the HRESIMS $\left(\mathrm{m} / z\right.$ 501.2616 $[\mathrm{M}+\mathrm{Na}]^{+}$, calcd for $\mathrm{C}_{30} \mathrm{H}_{38} \mathrm{O}_{5} \mathrm{Na}$, 501.2611) and ${ }^{13} \mathrm{C}$ NMR data, indicating twelve indexs of hydrogen 
deficiency. The IR spectrum showed the absorption bands for carbonyl groups at 1737 and $1758 \mathrm{~cm}^{-1}$. The ${ }^{1} \mathrm{H}$ NMR (Table S26) spectrum displayed four methyls $\left[\delta_{\mathrm{H}} 1.41(\mathrm{~d}\right.$, $J=7.2 \mathrm{~Hz}), 1.28(\mathrm{~s}), 1.10(\mathrm{~d}, J=7.2 \mathrm{~Hz})$, and $0.97(\mathrm{~s})]$, one olefinic methylene $\left[\delta_{\mathrm{H}}\right.$ $6.17(\mathrm{~d}, J=3.6 \mathrm{~Hz})$ and $5.45(\mathrm{~d}, J=3.0 \mathrm{~Hz})]$, and two oxygenated methines $\left[\delta_{\mathrm{H}} 4.63\right.$ and 4.39]. The ${ }^{13} \mathrm{C}$ NMR (Table S27) and DEPT spectra revealed thirty carbon signals, including one keto carbonyl group, two ester carbonyl groups, six quaternary carbons (three olefinic ones), eight methines (two oxygenated ones), nine methylenes (one olefinic), and four methyls.

The carbonyl groups and two double bonds accounted for five degrees of unsaturations, revealing the presence of seven rings in the structure of 1. Analysis of the ${ }^{1} \mathrm{H}-{ }^{1} \mathrm{H}$ COSY spectrum indicated three spin-coupling systems in bold in Figure 2 (I:

$$
\text { C-6-C-7-C-8-C-9-C-10 }
$$

II:

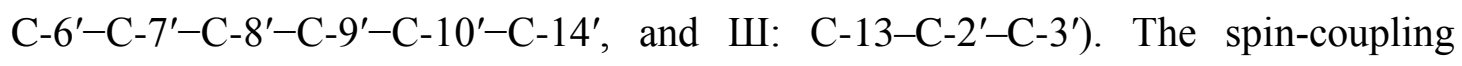
system I and the HMBC correlations from $\mathrm{H}-1$ to $\mathrm{C}-2 / \mathrm{C}-6$, from $\mathrm{H}_{2}-2 / \mathrm{H}_{2}-3$ to $\mathrm{C}-4$, from $\mathrm{H}_{3}-15$ to $\mathrm{C}-1 / \mathrm{C}-4 / \mathrm{C}-5$, from $\mathrm{H}_{2}-6$ to $\mathrm{C}-15$, and from $\mathrm{H}_{2}-13 / \mathrm{H}-7$ to $\mathrm{C}-11 / \mathrm{C}-12$ constructed a pseudoguaiaolide unit (A, in red). The spin-coupling systems II and III and the HMBC correlations from $\mathrm{H}_{2}-13^{\prime}$ to $\mathrm{C}-7^{\prime} / \mathrm{C}-11^{\prime} / \mathrm{C}-12^{\prime}$, from $\mathrm{H}_{3}-14^{\prime}$ to $\mathrm{C}-1^{\prime}$, from $\mathrm{H}_{2}-6^{\prime}$ to $\mathrm{C}-1^{\prime} / \mathrm{C}-5^{\prime}$, from $\mathrm{H}_{3}-15^{\prime}$ to $\mathrm{C}-4^{\prime} / \mathrm{C}-5^{\prime}$, and from $\mathrm{H}_{2}-3^{\prime}$ to $\mathrm{C}-1^{\prime} / \mathrm{C}-4^{\prime} / \mathrm{C}-5^{\prime}$ revealed the presence of a guaianolide unit ( $\mathrm{B}$, in black). In addition, the spin-coupling system $\amalg$ as well as the $\mathrm{HMBC}$ correlations from $\mathrm{H}-2^{\prime} / \mathrm{H}_{3}-15^{\prime}$ to $\mathrm{C}-11$ indicated that the two sesquiterpenoid units were connected via C-11-C-4' and C-13-C-2' bonds. The planar structure of $\mathbf{1}$ was thus established as an unprecedented 
2,4-linked pseudoguaianolide-guaianolide heterosesquiterpene lactone dimer.

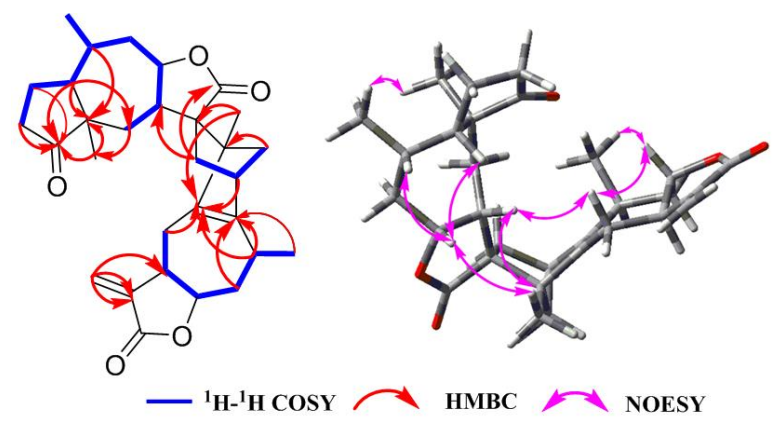

Figure 2. Key 2 D NMR correlations of 1.

The relative configuration of $\mathbf{1}$ was established on the basis of the NOESY spectrum, $J$ values, and the ECD spectrum. In unit A, the NOESY correlations of $\mathrm{H}_{3}-15 / \mathrm{H}_{3}-14, \mathrm{H}-10 / \mathrm{H}-8$, and $\mathrm{H}-8 / \mathrm{H}-1$ indicated that $\mathrm{H}-8, \mathrm{H}-10$, and $\mathrm{H}-1$ were $\alpha$-oriented and Me-14 and Me-15 were $\beta$-oriented. In unit B, the NOESY correlation of $\mathrm{H}_{3}-14^{\prime} / \mathrm{H}-8^{\prime}$ revealed that $\mathrm{H}-8^{\prime}$ and $\mathrm{H}-14^{\prime}$ were $\alpha$-oriented, while the coupling constants between $\mathrm{H}^{-} 7^{\prime}$ and $\mathrm{H}_{2}-13^{\prime}(J=3.6 \text { and } 3.0 \mathrm{~Hz})^{4}$ settled the $\beta$ orientation of H-7'. The downfield chemical shift of H-3'a $\left(\delta_{\mathrm{H}} 2.26\right)$ and the dominant negative Cotton effect $(\mathrm{CE})$ at $212 \mathrm{~nm}(\Delta \varepsilon=-16.2)$ indicated that compound $\mathbf{1}$ was an exo-SD. ${ }^{5}$ Finally, the relative configuration of 1 was assigned by the key NOESY correlations of $\mathrm{H}_{3}-15^{\prime} / \mathrm{H}-8, \mathrm{H}_{3}-15^{\prime} / \mathrm{H}-7, \mathrm{H}-6^{\prime} \alpha / \mathrm{H}-8^{\prime}$, and $\mathrm{H}-6^{\prime} \alpha / \mathrm{H}-7$ (Figure 2).

A diagnostic positive $\mathrm{CE}$ at $300 \mathrm{~nm}(\Delta \varepsilon=+3.1)$ due to the $n-\pi^{*}$ transition of the C-4 carbonyl group was observed in the ECD spectrum of $\mathbf{1}$, from which the absolute configuration of 1 was deduced as $1 S, 5 S, 7 R, 8 R, 10 S, 11 S, 2^{\prime} S, 4^{\prime} S, 7^{\prime} R, 8^{\prime} S, 10^{\prime} S$ by application of the cyclopentanone octant rule (Figure S20). ${ }^{6,4 b}$ To further confirm this conclusion, the ECD spectrum for the configuration of $(1 S, 5 S, 7 R, 8 R, 10 S, 11 S$, $\left.2^{\prime} S, \quad 4^{\prime} S, \quad 7^{\prime} R, \quad 8^{\prime} S, \quad 10^{\prime} S\right)-1$ was calculated at the B3LYP/dgdzvp and 
CAM-B3LYP/dgdzvp levels of theory (Supporting Information), and the calculated result matched well with the experimental data (Figure 3). Thus, the absolute configuration of compound $\mathbf{1}$ was unambiguously determined.

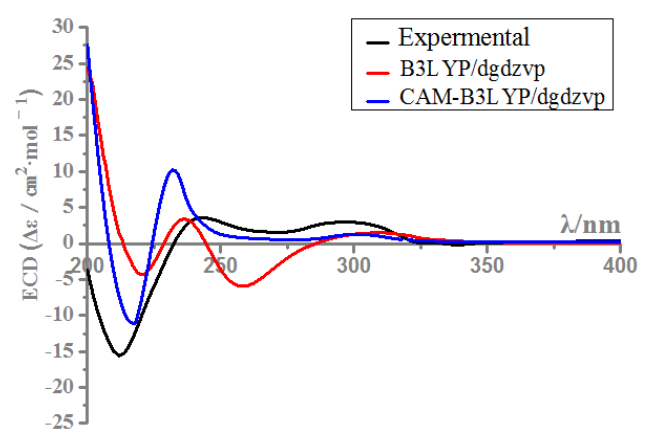

Figure 3. The ECD spectra of $\mathbf{1}$ (solvent: $\mathrm{CH}_{3} \mathrm{OH}$ ).

Heliaquanoid B (2) was obtained as a yellow crystal (in $\mathrm{CH}_{3} \mathrm{OH} / \mathrm{H}_{2} \mathrm{O}$ ). The HRESIMS ion peak at $m / z 501.2606\left([\mathrm{M}+\mathrm{Na}]^{+}\right)$revealed its molecular formula $\mathrm{C}_{30} \mathrm{H}_{38} \mathrm{O}_{5}$, with twelve degrees of unsaturation. The absorption bands at 1751 and $1762 \mathrm{~cm}^{-1}$ in the IR spectrum showed the presence of carbonyl groups. A detailed inspection of the ${ }^{13} \mathrm{C}$ NMR and DEPT spectra of 2 revealed the presence of four methyls, six olefinic carbons, two oxygenated methines and three carbonyl carbons.

The ${ }^{1} \mathrm{H}^{-1} \mathrm{H}$ COSY spectrum exhibited four spin-coupling systems (I: C-5-C-6-C-7-C-8-C-9-C-10-C-14, II: $\quad$ C-2-C-3, III:

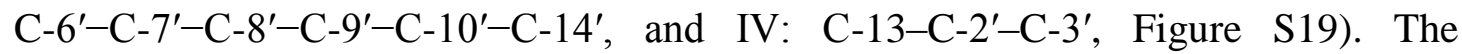
spin-coupling systems III and IV as well as the HMBC correlations (Figure S19) from $\mathrm{H}_{2}-13^{\prime}$ to $\mathrm{C}-7^{\prime} / \mathrm{C}-11^{\prime} / \mathrm{C}-12^{\prime}$, from $\mathrm{H}_{3}-14^{\prime} / \mathrm{H}_{2}-6^{\prime}$ to $\mathrm{C}-1^{\prime}$, from $\mathrm{H}_{3}-15^{\prime} / \mathrm{H}_{2}-6^{\prime}$ to $\mathrm{C}-5^{\prime}$, and from $\mathrm{H}_{3}-15^{\prime}$ to $\mathrm{C}-4^{\prime} / \mathrm{C}-3^{\prime}$ indicated the presence of a guaianolide unit ( $\mathrm{B}$, in black), which was the same as the unit B in compound $\mathbf{1}$. The spin-coupling system I, along with the HMBC correlations from $\mathrm{H}_{3}-15$ to $\mathrm{C}-4 / \mathrm{C}-3$, from $\mathrm{H}_{3}-14 / \mathrm{H}_{2}-2 / \mathrm{H}-5$ to $\mathrm{C}-1$, 
from $\mathrm{H}-7 / \mathrm{H}_{2}-13$ to $\mathrm{C}-11$, and from $\mathrm{H}_{2}-13 / \mathrm{H}-8$ to $\mathrm{C}-12$ constructed a xanthanolide unit (A, in blue). The linkage of units A and B was achieved by the spin-coupling system IV and the HMBC cross peaks from $\mathrm{H}_{3}-15^{\prime} / \mathrm{H}-3^{\prime}$ to $\mathrm{C}-11$ and from $\mathrm{H}_{2}-13$ to $\mathrm{C}-1^{\prime}$.

The downfield chemical shift of $\mathrm{H}-3^{\prime} \mathrm{a}\left(\delta_{\mathrm{H}} 2.33\right)$ and the negative $\mathrm{CE}$ at $220 \mathrm{~nm}$ $(\Delta \varepsilon=-11.0)$ implied that compound 2 was also an exo-SD. In the NOESY spectrum, the correlations of $\mathrm{H}-8 / \mathrm{H}-10$ and $\mathrm{H}_{3}-15^{\prime} / \mathrm{H}-8, \mathrm{H}_{3}-15^{\prime} / \mathrm{H}-7$ revealed that the relative configurations of unit $\mathrm{A}$ and the bridged ring were similar to those of compound $\mathbf{1}$. Moreover, the NOESY correlations of $\mathrm{H}-6^{\prime} \alpha / \mathrm{H}-8^{\prime}, \mathrm{H}-6^{\prime} \alpha / \mathrm{H}-7$, and $\mathrm{H}-8^{\prime} / \mathrm{H}-14^{\prime}$ suggested that the relative configuration of unit B of $\mathbf{2}$ was the same as that of $\mathbf{1}$.

The single-crystal X-ray diffraction experiment $(\mathrm{Cu} \mathrm{K} \alpha$ radiation, Figure 4) and the quantum mechanical calculations (Figure 5) established unambiguously the absolute configurations of 1 to be $7 R, 8 R, 10 S, 11 S, 2^{\prime} S, 4^{\prime} S, 7^{\prime} R, 8^{\prime} S, 10^{\prime} S$.

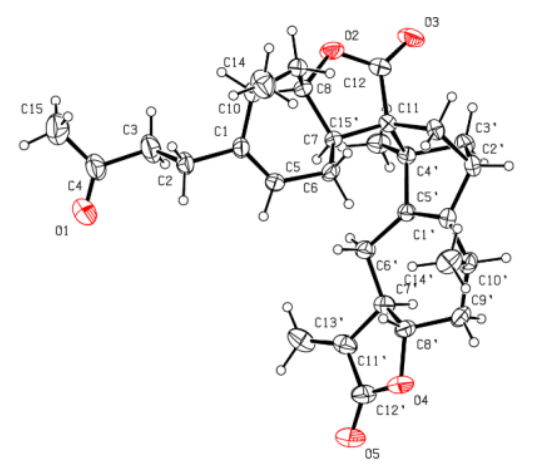

Figure 4. X-ray structure (displacement ellipsoids are drawn at the 16\% probability level) of 2.

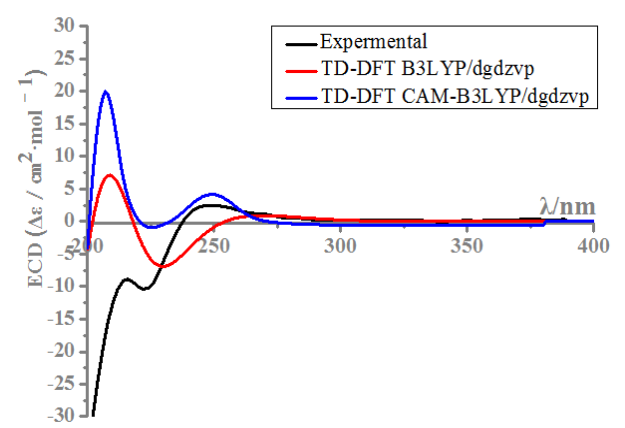

Figure 5. ECD spectra of 2 (solvent: $\mathrm{CH}_{3} \mathrm{OH}$ ). 
Heliaquanoids C (3) and D (4) shared the same molecular formula $\mathrm{C}_{30} \mathrm{H}_{40} \mathrm{O}_{5}$, based on the HRESIMS ion peaks at $m / z 503.2762$ and $503.2761[\mathrm{M}+\mathrm{Na}]^{+}$for 3 and 4, respectively. Similar NMR spectra revealed that $\mathbf{3}$ and $\mathbf{4}$ had the same carbon skeleton as $\mathbf{2}$. Whereas, the absence of the carbonyl carbon at $\delta_{\mathrm{C}} 208.2(\mathrm{C}-4)$ in $\mathbf{2}$ and the presence of an oxygenated methine $\delta_{\mathrm{H}} 3.72 / \delta_{\mathrm{C}} 67.8$ in 3 and $\delta_{\mathrm{H}} 3.77 / \delta_{\mathrm{C}} 67.9$ in 4 indicated that the carbonyl at C-4 in $\mathbf{2}$ was reduced to the hydroxy group in $\mathbf{3}$ and $\mathbf{4}$. This deduction was further confirmed by the spin-coupling system C-15-C-4-C-3-C-2 in the ${ }^{1} \mathrm{H}-{ }^{1} \mathrm{H}$ COSY spectrum. In the ${ }^{1} \mathrm{H}$ NMR spectra, the differences between compounds 3 and $\mathbf{4}$ were the downfield H-2', H-9'a, and H-14' at $\delta_{\mathrm{H}} 2.98,2.40$, and 1.30 in $\mathbf{4}$, in contrast to $\delta_{\mathrm{H}} 2.58,2.19$, and 1.14 in $\mathbf{3}$, and the upfield $\mathrm{H}-9^{\prime} \mathrm{b}$ and $\mathrm{H}-10^{\prime}$ at $\delta_{\mathrm{H}} 1.63$ and 2.32 in 4, in contrast to $\delta_{\mathrm{H}} 1.94$ and 2.91 in $\mathbf{3}$. And in the ${ }^{13} \mathrm{C}$ NMR spectra, the chemical shifts of C-2', C-8', C-9', C-10', and C-14' were changed from $\delta_{\mathrm{C}} 48.4,81.4,39.5,32.6$, and 19.9 in 3 to $\delta_{\mathrm{C}} 42.8,84.7,40.9,29.8$, and 21.7 in 4 . Inspection of the $2 \mathrm{D}$ NMR data of $\mathbf{4}$ indicated that its $2 \mathrm{D}$ structure was identical to that of $\mathbf{3}$.

The relative configuration of ring systems in $\mathbf{3}$ was proposed as being the same as that of $\mathbf{2}$ on the basis of similar NOESY correlations. Additionally, the NOESY correlations of $\mathrm{H}-8^{\prime} / \mathrm{H}-10^{\prime}$ in $\mathbf{4}$ confirmed that compound $\mathbf{4}$ was the $\mathrm{C}-10^{\prime}$ epimer of $\mathbf{3}$. The absolute configuration of the secondary hydroxy group at C-4 in $\mathbf{3}$ was established by the modified Mosher's method. Compound 3 was treated with $(R)$ - and $(S)$-MTPA-Cl, and then the $(S)$ - and $(R)$-MTPA esters at C-4 of $\mathbf{3}$ were obtained. Subsequently, analysis of the $\Delta \delta$ values in the ${ }^{1} \mathrm{H}$ NMR spectra for the two esters led 
to the assignment of the $S$-configuration at C-4 in $\mathbf{3}$ (Figure S9). The same chemical shifts of the side chain in compounds $\mathbf{3}$ and $\mathbf{4}$ suggested that the absolute configuration at C-4 of $\mathbf{4}$ was also $S$-configuration.

The ECD spectra of compounds 3 and $\mathbf{4}$ were similar to that of 2 (Figure S21). Thus, the absolute configurations of compounds 3 and $\mathbf{4}$ were elucidated as $4 S, 7 R, 8 R$, $10 S, 11 S, 2^{\prime} S, 4^{\prime} S, 7^{\prime} R, 8^{\prime} S, 10^{\prime} S$ and $4 S, 7 R, 8 R, 10 S, 11 S, 2^{\prime} S, 4^{\prime} S, 7^{\prime} R, 8^{\prime} S, 10^{\prime} R$, respectively.

Heliaquanoid E (5) was a yellow oil. The HRESIMS $(\mathrm{m} / \mathrm{z} \text { 503.2758, [M + Na }]^{+}$, calcd 503.2768) indicated the molecular formula of $\mathrm{C}_{30} \mathrm{H}_{40} \mathrm{O}_{5}$, which was identical to that of 3. Meanwhile, comprehensive analysis of the 1D and 2D NMR spectra constructed the same units A (xanthanolide moiety) and B (guaianolide moiety) as those of 3. Furthermore, the relative configurations of units $\mathrm{A}$ and $\mathrm{B}$ of $\mathbf{5}$ were elucidated as the same as those of $\mathbf{3}$ by the similar NOESY correlations (Figure 6). The endo stereochemistry of $\mathbf{5}$ was established on the basis of the upfield chemical shift of H-3'a at $\delta_{\mathrm{H}} 1.40$ and the positive CE at $232 \mathrm{~nm}(\Delta \varepsilon=+34.2) .{ }^{5}$ Finally, the NOESY correlation of $\mathrm{H}-10^{\prime}$ with $\mathrm{H}-13 \beta$ completed the relative configuration of 5.

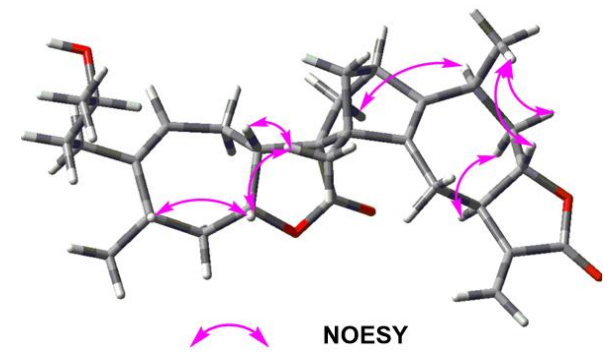

Figure 6. NOESY correlations of 5 . 
The absolute configuration at C-4 was also determined to be $S$ by the same modified Mosher's method (Table S25). To determine the absolute structure of the ring systems, the ECD curves for the 5-1 (4S, 7R, 8R, 10S, 11S, $\left.2^{\prime} R, 4^{\prime} R, 7^{\prime} R, 8^{\prime} S, 10^{\prime} S\right)$ and the 5-2 (4S, 7S, $\left.8 S, 10 R, 11 R, 2^{\prime} S, 4^{\prime} S, 7^{\prime} S, 8^{\prime} R, 10^{\prime} R\right)$ were both calculated. The experimental ECD spectrum of 5 was similar to the calculated data of 5-1 (Figure 7). Accordingly, the absolute configuration of compound 5 was determined to be $4 S, 7 R$, $8 R, 10 S, 11 S, 2^{\prime} R, 4^{\prime} R, 7^{\prime} R, 8^{\prime} S, 10^{\prime} S$.

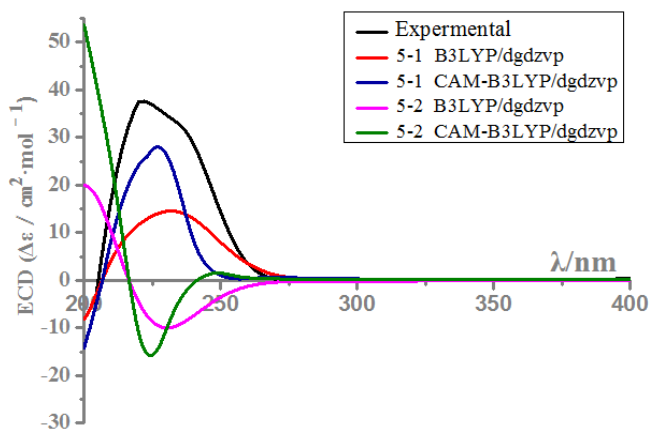

Figure 7. ECD spectra (solvent: $\mathrm{CH}_{3} \mathrm{OH}$ ) of $\mathbf{5}$.

The cytotoxic activity of these isolated compounds against four human cancer cell lines (A549, MCF-7, HL-60, and SMCC-7721) was evaluated using the MTT assay (Table 1). Compounds $\mathbf{2}$ and $\mathbf{3}$ showed moderate cytotoxic activities against HL-60 (human premyelocytic leukemia) cells with $\mathrm{IC}_{50}$ values of 7.5 and $4.9 \mu \mathrm{M}$, respectively.

Table 1. $\mathrm{IC}_{50}$ Values $(\mu \mathrm{M})$ for Antiproliferative Activity of Compounds 1-5.

\begin{tabular}{|c|c|c|c|c|}
\hline \multirow{2}{*}{ Compound } & \multicolumn{4}{|c|}{$\mathrm{IC}_{50}(\mu \mathrm{M})^{a}$} \\
\cline { 2 - 5 } & A549 & SMCC-7721 & MCF-7 & HL-60 \\
\hline $\mathbf{1}$ & $29.0 \pm 0.50$ & $29.1 \pm 0.21$ & $18.1 \pm 0.78$ & $17.3 \pm 0.40$ \\
\hline $\mathbf{2}$ & $13.2 \pm 0.70$ & $15.7 \pm 0.06$ & $8.6 \pm 0.29$ & $7.5 \pm 0.23$ \\
\hline $\mathbf{3}$ & $8.7 \pm 0.29$ & $13.3 \pm 0.10$ & $8.2 \pm 0.99$ & $4.9 \pm 0.06$ \\
\hline $\mathbf{4}$ & $21.1 \pm 0.64$ & $25.2 \pm 0.67$ & $14.0 \pm 0.75$ & $11.7 \pm 0.33$ \\
\hline
\end{tabular}




\begin{tabular}{|c|c|c|c|c|}
$\mathbf{5}$ & $19.2 \pm 2.50$ & $23.2 \pm 1.20$ & $9.2 \pm 0.92$ & $9.6 \pm 0.31$ \\
\hline cisplatin $^{b}$ & $5.52 \pm 0.30$ & $4.38 \pm 0.12$ & $3.56 \pm 0.34$ & $1.47 \pm 0.10$ \\
\hline doxorubicin $^{b}$ & $1.16 \pm 0.14$ & $0.98 \pm 0.27$ & $0.63 \pm 0.30$ & $0.79 \pm 0.25$ \\
\hline
\end{tabular}

${ }^{a}$ The data were expressed as means \pm standard deviation, ${ }^{b}$ cisplatin and doxorubicin as the positive controls.

In conclusion, five new 2,4-linked SDs were isolated from Inula helianthus-aquatica. Heliaquanoid A (1) is the first 2, 4-linked pseudoguaianolide and guaianolide heterosesquiterpane lactone dimer, and heliaquanoids $\mathrm{B}-\mathrm{E}$ (2-5) represent the rare class of SDs. These compounds increase the chemical diversity of sesquiterpenoid dimers in nature. Moreover, heliaquanoids $\mathrm{B}$ and $\mathrm{C}$ exhibited the moderate cytotoxicities against HL-60 cells.

\section{EXPERIMENTAL SECTION}

General Experimental Procedures: Melting points were measured on an X-5 micromelting point apparatus (Tech, Beijing, P. R. China). A Perkin-Elmer 341 polarimeter was used for measuring optical rotations. A Nicolet NEXUS 670 FT-IR spectrometer was used to measure infrared absorptions. ${ }^{1} \mathrm{H},{ }^{13} \mathrm{C}$, and $2 \mathrm{D}$ NMR spectroscopic data were performed on a Varian Mercury-600BB or Bruker Avance III-400 instrument. A JASCO J-720 spectropolarimeter was used to get ECD spectroscopic data. A Bruker APEXII mass spectrometer was used to get HRESIMS data. X-ray crystallography analysis was conducted on a SuperNova, Dual, Eos diffractometer using graphic monochromated $\mathrm{Cu} \mathrm{Ka}$ radiation. Sephadex LH-20 (Amersham Pharmacia Biotech), silica gel (200-300 mesh, Qingdao Marine Chemical Factory, China), and RP-C $\mathrm{C}_{18}$ silica gel (150-200 mesh, Merck) were used 
for column chromatography. Semipreparative HPLC with a reversed-phase $\mathrm{C}_{18}(150 \times$ $10 \mathrm{~mm}, 10 \mu \mathrm{m})$ column was used for the isolation and purification of samples. TLC was carried out on $\mathrm{GF}_{254}$ plates.

Plant Materials. The stems and leaves of Inula helianthus-aquatica were collected in Zhao-tong, Yunnan Province, China, in September 2017 and identified by Zhang Guoliang, a professor at Lanzhou University. A voucher specimen (no. 20170921) was stored at the Natural Product Laboratory of State Key Laboratory of Applied Organic Chemistry, Lanzhou University.

Extraction, Isolation, and Purification Process. At room temperature, the stems and leaves of Inula helianthus-aquatica $(10 \mathrm{~kg})$ were chipped and extracted three times with $\mathrm{MeOH}(5 \times 25 \mathrm{~L}, 7$ days each time $)$. After filtration and solvent evaporation, the residue ( $1 \mathrm{~kg}$ ) was suspended in $\mathrm{H}_{2} \mathrm{O}$ and extracted with $\mathrm{CH}_{2} \mathrm{Cl}_{2}$ and n-BuOH, successively. The $\mathrm{CH}_{2} \mathrm{Cl}_{2}$ extract (376 g) was chromatographed over macroporous resin, eluted with gradient mixtures of $\mathrm{EtOH}-\mathrm{H}_{2} \mathrm{O}$ (from 0:100 to 100:0) to give six fractions $(\mathrm{A}-\mathrm{F})$. Fractions $1-7$ were separated from fraction $\mathrm{D}(131 \mathrm{~g})$ by a silica gel column (petroleum ether/acetone, 2:1). Fraction 4 (17 g) was subjected to Sephadex $\mathrm{LH}-20\left(\mathrm{MeOH} / \mathrm{CHCl}_{3}, 1: 1\right)$ and further separated over RP-18 silica gel $\left(\mathrm{MeOH} / \mathrm{H}_{2} \mathrm{O}, 1: 1-1: 0\right)$ to afford fractions $4.1-4.5$. Then fraction 4.3 was subjected to Sephadex LH-20 (MeOH) to yield fractions 4.3.1-4.3.4. Compounds 2 (15 mg) and $\mathbf{3}$ (10 mg) were separated from fraction 4.3.3.1 by semi-preparative HPLC $\left(\mathrm{CH}_{3} \mathrm{OH} / \mathrm{H}_{2} \mathrm{O}, 75 \%\right)$. Using the same procedures, compounds $4(7 \mathrm{mg})$ and $5(12 \mathrm{mg})$ were obtained from fraction 4.3.3.2 and fraction 4.3.3.3, respectively. Fraction 4.3.3.4 
was chromatographed on a silica gel column (petroleum ether/acetone, 5:1-1:1), followed by semi-preparative $\mathrm{HPLC}\left(\mathrm{CH}_{3} \mathrm{CN} / \mathrm{H}_{2} \mathrm{O}, 55 \%\right)$ to afford compound 1 (3 $\mathrm{mg})$.

Heliaquanoid A (1): Colorless oil; $[\alpha]^{25} \mathrm{D}=+85.0(c 0.2, \mathrm{MeOH})$; IR $(\mathrm{KBr}) v_{\max }$ $2930,1758,1737,1595,1459,1378,1258,1146 \mathrm{~cm}^{-1}$; UV $(\mathrm{MeOH}) \lambda_{\max }(\log \varepsilon)=254$ (0.744) nm; ${ }^{1} \mathrm{H}$ and ${ }^{13} \mathrm{C}$ NMR data, see Tables S26 and S27; HRMS (ESI-Orbitrap) $m / z:[\mathrm{M}+\mathrm{Na}]^{+}$calcd for $\mathrm{C}_{30} \mathrm{H}_{38} \mathrm{O}_{5} \mathrm{Na} 501.2611$; found, 501.2616.

Heliaquanoid B (2): Yellow crystal in $\mathrm{CH}_{3} \mathrm{OH} / \mathrm{H}_{2} \mathrm{O}$; m.p.: $162-164{ }^{\circ} \mathrm{C} ;[\alpha]^{24} \mathrm{D}=$ +10.0 (c 0.2, MeOH); IR (KBr) $v_{\max } 2927,1762,1751,1737,1459,1258,1145 \mathrm{~cm}^{-1}$; $\mathrm{UV}(\mathrm{MeOH}) \lambda_{\max }(\log \varepsilon)=254(0.692) \mathrm{nm} ;{ }^{1} \mathrm{H}$ and ${ }^{13} \mathrm{C}$ NMR data, see Tables S26 and S27; HRMS (ESI-Orbitrap) $m / z:[\mathrm{M}+\mathrm{Na}]^{+}$calcd for $\mathrm{C}_{30} \mathrm{H}_{38} \mathrm{O}_{5} \mathrm{Na}$ 501.2611; found, 501.2606.

Heliaquanoid C (3): Colorless oil; $[\alpha]^{24}{ }_{\mathrm{D}}=-5.0\left(c^{0} 0.2, \mathrm{MeOH}\right)$; IR $(\mathrm{KBr}) v_{\max }$ 3396, 2956, 2928, 1752, 1459, $1258 \mathrm{~cm}^{-1}$; UV (MeOH) $\lambda_{\max }(\log \varepsilon)=254(0.791) \mathrm{nm}$; ${ }^{1} \mathrm{H}$ and ${ }^{13} \mathrm{C}$ NMR data, see Tables S26 and S27; HRMS (ESI-Orbitrap) $m / z:[\mathrm{M}+\mathrm{Na}]^{+}$ calcd for $\mathrm{C}_{30} \mathrm{H}_{40} \mathrm{O}_{5} \mathrm{Na}$ 503.2768; found, 503.2762

Heliaquanoid D (4): Colorless oil; $[\alpha]^{25} \mathrm{D}=+5.0(c 0.2, \mathrm{MeOH})$; IR $(\mathrm{KBr}) v_{\max }$ $3377,2926,1753,1597,1459,1260,1121 \mathrm{~cm}^{-1} ; \mathrm{UV}(\mathrm{MeOH}) \lambda_{\max }(\log \varepsilon)=254(0.978)$ nm; ${ }^{1} \mathrm{H}$ and ${ }^{13} \mathrm{C}$ NMR data, see Tables S26 and S27; HRMS (ESI-Orbitrap) $m / z:[\mathrm{M}+$ Na] $]^{+}$calcd for $\mathrm{C}_{30} \mathrm{H}_{38} \mathrm{O}_{5} \mathrm{Na}$ 503.2768; found, 503.2761.

Heliaquanoid E (5): Yellow oil; $[\alpha]^{25} \mathrm{D}=+270.0(c 0.2, \mathrm{MeOH})$; IR $(\mathrm{KBr}) v_{\max }$ $3409,2958,2931,2871,1757,1460,1257,1204,1158,1139,736 \mathrm{~cm}^{-1}$; UV (MeOH) 
$\lambda_{\max }(\log \varepsilon)=254(0.612) \mathrm{nm} ;{ }^{1} \mathrm{H}$ and ${ }^{13} \mathrm{C}$ NMR data, see Tables S26 and S27; HRMS (ESI-Orbitrap) $m / z:[\mathrm{M}+\mathrm{Na}]^{+}$calcd for $\mathrm{C}_{30} \mathrm{H}_{38} \mathrm{O}_{5} \mathrm{Na}$ 503.2768; found, 503.2758.

X-ray Crystallographic Analysis of 2: Colorless crystals of 2 were obtained from $\mathrm{MeOH}$ and $\mathrm{H}_{2} \mathrm{O}$. A single crystal of dimensions $0.15 \times 0.14 \times 0.12 \mathrm{~mm}^{3}$ was used for X-ray measurements. Crystal data: $\mathrm{C}_{30} \mathrm{H}_{38} \mathrm{O}_{5}$, space group $\mathrm{P} 2$ (1), $a=$ 7.6807(2) $\mathrm{A}, b=10.5907(3) \AA, c=16.1738(4) \AA, \alpha=90.00^{\circ}, \beta=101.009(3)^{\circ}, \gamma=$ $90.00^{\circ}, \mathrm{V}=1291.43(6) \AA^{3}, \mathrm{Z}=2, D_{\text {calc }}=1.231 \mathrm{~g} / \mathrm{cm}^{3}, \mathrm{R}_{1}=0.0459, w \mathrm{R}_{2}=0.1185$. The supplementary crystallographic data for $\mathbf{2}$ reported in this paper have been deposited at the Cambridge Crystallographic Data Centre (Deposition No. CCDC 1854177). Copies of these data can be obtained free of charge via www.ccdc.cam.ac.uk/conts/retrieving.html.

Modified Mosher's Method ${ }^{7}(R)$-MTPA chloride $(5.0 \mu \mathrm{L})$ and DMAP (1.0 $\mathrm{mg}$ ) were added to a solution of $3(3.0 \mathrm{mg})$ in pyridine- $\mathrm{d}_{5}(0.5 \mathrm{~mL})$ to prepare the $(S)$-MTPA ester. Then the mixture was transferred to a NMR tube and warmed in oil bath at $40^{\circ} \mathrm{C}$ for overnight. The $(R)$-MTPA ester of $\mathbf{3}$ was prepared by the same method. Then, the $\Delta \delta$ values of the ${ }^{1} \mathrm{H}$ NMR for two esters were calculated. And the $(R)$ - and $(S)$-MTPA esters of $\mathbf{5}$ were prepared using the same method.

Cytotoxicity Assay ${ }^{8}$ Cytotoxic activity of the compounds against A549, SMCC-7721, MCF-7, and HL-60 cell lines were evaluated using the MTT assay. Briefly, amount of cells were incubated with graded concentrations of the tested compounds in 96-well plates (Falcon, CA) for $44 \mathrm{~h}$ at $37{ }^{\circ} \mathrm{C}$ in a final volume of 100 $\mu \mathrm{L}$. Cells treated with DMSO alone were used as controls. At the end of the treatment, 
$10 \mu \mathrm{L}$ MTT ( $5 \mathrm{mg} / \mathrm{mL}$ ) was added to each well and incubated for an additional $4 \mathrm{~h}$ at

$37^{\circ} \mathrm{C}$. After addition of the extraction buffer (100 $\mu \mathrm{L}, 10 \%$ SDS, $5 \%$ isobutanol, $0.1 \%$ $\mathrm{HCl}$ ), cells were further incubated overnight. A microplate reader (Thermo Scientific Multiskan GO, Finland) was used to measure absorbance $(570 \mathrm{~nm})$.

\section{ASSOCIATED CONTENT}

\section{Supporting Information}

1D and 2D NMR, HRESIMS, and IR spectra of heliaquanoids A-E (1-5) and the crystallographic data of $\mathbf{2}$ are available free of charge via the Internet at http://pubs.acs.org.

\section{AUTHOR INFORMATION}

\section{Corresponding Author}

* E-mail: npchem@1zu.edu.cn. (K. Gao)

liea@1zu.edu.cn. (Y. Li)

\section{ORCID}

Kun Gao: 0000-0002-3856-3672

\section{Notes}

The authors declare no competing financial interest.

\section{ACKNOWLEDGMENT}

This project was supported by the National Natural Science Foundation of China (No. 21778027).

Bencan Tang would like to acknowledge the University of Nottingham for the 
use of the High Performance Computing Facility.

\section{REFERENCES}

(1) (a) Zhan, Z. J.; Ying, Y. M.; Ma, L. F.; Shan, W. G. Natural disesquiterpenoids. Nat. Prod. Rep. 2011, 28, 594-629. (b) Li. X. G.; Yang. X. Y.; Liu, Y. L.; G, N. X.; Yao, W. B.; Chen, P. Z.; Qin, J. J.; Jin, H. Z.; Li, J. Q.; Chu, R. A.; Shan, L.; Zhang, R. W.; Zhang, W. D.; Wang, H. Japonicone A suppresses growth of burkitt lymphoma cells through its effect on NF- $\kappa$ B. Clin. Cancer Res. 2013, 19, 2917-2928. (c) Yang, Y. X.; Shan, Lei.; Liu. Q. X.; Shen.; Y. Heng.; Zhang, J. P.; Ye J.; Xu, X. K.; Li, H. L.; Zhang, W. D. Carpedilactones A-D, four new isomeric sesquiterpene lactone dimers with potent cytotoxicity from Carpesium faberi. Org. Lett. 2014, 16, 4216-4219. (d) Zhang, J. P.; Xu, X. K.; Ye, J.; Yang, Y. X.; Gao, S.; Li, H. L.; Zhang, W. D. Three new sesquiterpene lactone dimers from Carpesium macrocephalum. Fitoterapia $\mathbf{2 0 1 6}$ 110, 72-76. (e) Xu, X. K.; Ye, J.; Chen. L. P.; Zhang, W. D.; Yang, Y. X.; Li, H. L. Three new sesquiterpene lactone dimers from Carpesium faberi. Phytochem. Lett. 2016, 16, 277-282. (f) Zhou, B.; Liu, Q. F.; Dalal, S.; Cassera. M. B.; Yue, J. M. Fortunoids $\mathrm{A}-\mathrm{C}$, three sesquiterpenoid dimers with different carbon skeletons from Chloranthus fortune. Org. Lett. 2017, 19, 734-737. (g) Zhang, Y. L.; Zhou, X. W.; Wang, X. B.; Wu, L.; Yang, M. H.; Luo, J.; Yin, Y.; Luo, J. G.; Kong, L. Y. Xylopiana A, a dimeric guaiane with a case-shaped core from Xylopia vielana: structural elucidation and biomimetic conversion. Org. Lett. 2017, 19, 3013-3016. (h) Qin, D. P.; Pan, D. B.; Xiao, W.; Li, H. B.; Yang, B.; Yao, X. J.; Dai, Y.; Yu, Y.; Yao. X. S. Dimeric cadinane sesquiterpenoid derivatives from Artemisia annua. Org. Lett. 
2018, 20, 453-456.

(2) (a) Qin, J. J.; Wang, L. Y.; Zhu, J. X.; Jin, H. Z.; Fu, J. J.; Liu, X. F.; Li, H. L.; Zhang, W. D. Neojaponicone A, a bioactive sesquiterpene lactone dimer with an unprecedented carbon skeleton from Inula japonica. Chem. Commun. 2011, 47, 1222-1224. (b) Qin, J. J.; Huang, Y.; Wang, D.; Cheng, X. R.; Zheng, Q.; Zhang, S. D.; Hu, Z. L.; Jin, H. Z.; Zhang, W. D. Lineariifolianoids A-D, rare unsymmetrical sesquiterpenoid dimers comprised of xanthane and guaiane framework units from Inula lineariifolia. RSC Adv. 2012, 2, 1307-1309. (c) Qin, J. J.; Jin, H. Z.; Huang, Y.; Zhang, S. D.; Shan, L.; Voruganti, S.; Nag, S.; Wang, W.; Zhang, W, D.; Zhang, R. Selective cytotoxicity, inhibition of cell cycle progression, and induction of apoptosis in human breast cancer cells by sesquiterpenoids from Inula lineariifolia Turcz. Eur. J. Med. Chem. 2013, 68, 473-481. (d) Xu, X. Yu.; Sun, P.; Guo, D. A.; Liu, X.; Liu, J. H.; Hu, L. H. Cytotoxic sesquiterpene lactone dimers isolated from Inula japonica. Fitoterapia 2015, 101, 218-223.

(3) (a) Jakupovic, J.; Zdero, C.; Grenz, M.; Tsichritzis, F.; Lehmann, L.; Hashemi-Nejad, S. M.; Bohlmann, F. Twenty-one acylphloroglucinol derivatives and further constituents from south african Helichrysum species. Phytochemistry 1989, 28, 1119-1131. (b) Zdero, C.; Bohlmann, F. Sesquiterpene lactones and other terpenes from Geigeria species. Phytochemistry 1989, 28, 3105-3120.

(4) (a) Bohlmann, F.; Zdero, C.; King, R. M.; Robinson, H. Pseudoguaianolides and other sesquiterpene lactones from Gaillardia species. Phytochemistry 1984, 23, 1979-1988. (b) Qin, J, J.; Zhu, J. X.; Zeng, Q.; Cheng, X, R.; Zhu, Y.; Zhang, S. D.; 
Shan, L.; Jin, H. Z.; Zhang, W. D. Pseudoguaianolides and guaianolides from Inula hupehensis as potential anti-inflammatory agents. J. Nat. Prod. 2011, 74, 1881-1887.

(5) (a) Yang, Y. X.; Gao, S.; Zhang, S. D.; Zu, X. P.; Shen, Y. H.; Shan, L.; Li, H. L.; Zhang, W. D. Cytotoxic 2,4-linked sesquiterpene lactone dimers from Carpesium faberi exhibiting NF- $\kappa \mathrm{B}$ inhibitory activity. RSC Adv. 2015, 5, 55285-55289. (b) Xu, X. K.; Ye, J.; Chen, L. P.; Zhang, W. D.; Yang, Y. X.; Li, H. L. Four new isomeric sesquiterpene lactone dimers from Carpesium faberi. Tetrahedron Lett. 2015, 56, $6381-6384$

(6) (a) Sondheimer, F.; Burstein, S.; Mechoulan, R. Synthesis in the cardiac aglycon field. III. The conversion of a $14 \alpha$ - to a $14 \beta$-hydroxy group in the androstane series. The ultraviolet spectra of $\Delta^{15}$-androsten-17-ones. J. Am. Chem. Soc. 1960, 82, 3209-3214. (b) Klyne, W. Optical rotatory dispersion. Some applications to structural and stereochemical problems in organic chemistry. Tetrahedron 1961, 13, 29-47.

(7) (a) Dale, J. A.; Masher, H. S. Nuclear magnetic resonance enantiomer reagents. configurational correlations via nuclear magnetic resonance chemical shifts of diastereomeric mandelate, $\quad o$-methylmandelate, and $\alpha$-methoxy- $\alpha$-trifluoromethylphenylacetate (MTPA) esters. J. Am. Chem. Soc. 1973, 95, 512-519. (b) Ohtani, I.; Kusumi, T.; Kashman, Y.; Kakisawa, H. High-field FT NMR application of Mosher's method. The absolute configurations of marine terpenoids. J. Am. Chem. Soc. 1991, 113, 4092-4096. (c) Jang, H. J.; Lee, S. J.; Lee, S.; Jung. K.; Lee, S. W.; Rho. M. C. Acyclic triterpenoids from Alpinia katsumadai inhibit IL-6-induced STAT3 activation. Molecules 2017, 22, 1611. 
(8) Yin, H. W.; Li, J.; Xiong, K.; Wang, L. H.; Wang, T. Y.; Tan, Q.; Fu, J. N.; Ren, X. Y.; Zeng, H. H. Novel mechanism of ethaselen in poorly differentiated colorectal RKO cell growth inhibition: simultaneous regulation of TrxR transcription, expression and enzyme activity. Differentiation 2011, 81, 49-56. 


\section{Table of content}

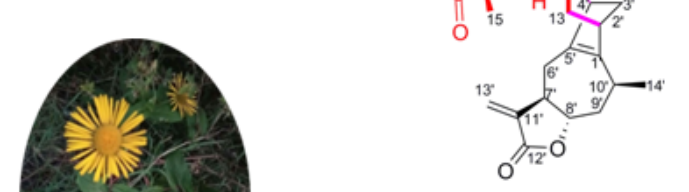

Heliaquanoid A(1)

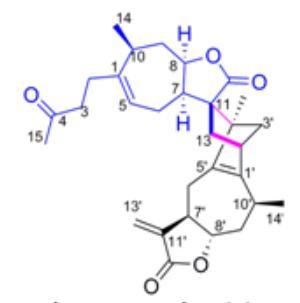

Heliaquanoid B (2)

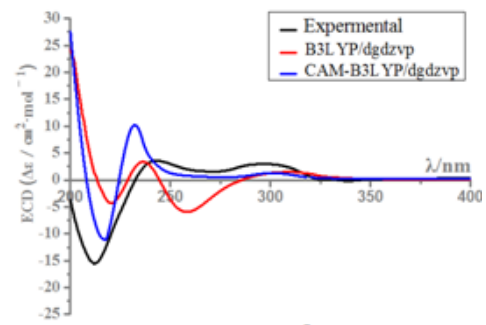

ECD spectra of 1

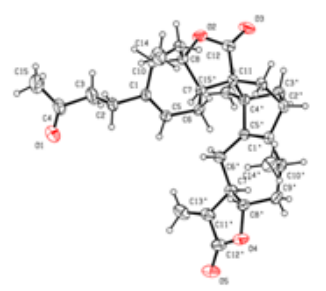

Crystal structure of 2 